\title{
Plasticity in life history traits of the native Proterorhinus semilunaris suggests high adaptive capacity in its invasive range
}

\author{
Nildeniz Top ${ }^{1}$, Uğur Karakuş ${ }^{1}$, Erdi Gökhan Tepeköy ${ }^{1}$, John Robert Britton ${ }^{2}$ and Ali Serhan Tarkan ${ }^{1,3, *}$ \\ ${ }^{1}$ Research and Application Unit, Faculty of Fisheries, Muğla Sitkı Koçman University, 48000 Kötekli, Muğla, Turkey \\ ${ }^{2}$ Department of Life and Environmental Sciences, Faculty of Science and Technology, Bournemouth University, BH12 5BB, UK \\ ${ }^{3}$ Department of Ecology and Vertebrate Zoology, Faculty of Biology and Environmental Protection, \\ University of Łódź, Łódź, Poland
}

\begin{abstract}
Invasion risk assessments are reliant on ecological data that assist the predictions of whether an introduced species will adapt to novel conditions. Data from the native range of potential invaders can thus assist these assessments. Here, the growth and reproductive characteristics of the Western tubenose goby Proterorhinus semilunaris, a Ponto-Caspian gobiid, were assessed in three natural lakes in their native range, as there are few extant data on these traits. Across the three lakes, the gobies were found in varying abundances. Sex ratios varied, with females significantly outnumbering males in only one lake, with equal sex ratios in the other lakes. The fish always showed a positive allometric growth, but had high variability in their somatic growth rates and relative body conditions between the lakes. Scale ageing revealed all populations comprised of individuals to four years old, with one lake having individuals to 5 years old. Reproductive characteristics, including size at maturity, gonado-somatic index and fecundity, did not differ significantly between the lakes. These data suggest that plasticity in aspects of their life history traits provides $P$. semilunaris with considerable adaptive capacity following their introduction into novel conditions.
\end{abstract}

Keywords: tubenose goby / alien / age / growth / deep lakes

Résumé - La plasticité des traits de vie de Proterorhinus semilunaris indigène suggère une grande capacité d'adaptation dans son aire de répartition potentielle. Les évaluations des risques d'invasion reposent sur des données écologiques qui aident à prédire si une espèce introduite s'adaptera à de nouvelles conditions. Les données de l'aire de répartition indigène des envahisseurs potentiels peuvent donc faciliter ces évaluations. Ici, les caractéristiques de croissance et de reproduction du gobie demi-lune Proterorhinus semilunaris, un gobiidé Ponto-Caspien, ont été évaluées dans trois lacs naturels de leur aire d'origine. Bien que ce poisson ait une distribution de plus en plus envahissante, il existe peu de données sur ces caractères. Dans les trois lacs, les gobies ont été trouvés en abondance variable. Les sexe ratios variaient, les femelles étant nettement plus nombreuses que les mâles dans un seul lac, les sexe ratios étant équilibrés dans les autres lacs. Les poissons ont toujours montré une croissance allométrique positive, mais leur taux de croissance somatique et leur état corporel relatif entre les lacs étaient très variables. La scalimétrie a révélé que toutes les populations étaient composées d'individus âgés de quatre ans, un lac ayant des individus âgés de cinq ans et moins. Les caractéristiques de reproduction, comme la taille à maturité, l'indice gonadique somatique et la fécondité, ne différaient pas de façon significative entre les lacs. Ces données suggèrent que la plasticité dans certains aspects de son cycle biologique confère à $P$. semilunaris une capacité d'adaptation considérable après introduction dans de nouvelles conditions.

Mots-clés : gobie demi-lune / exotique / âge / croissance / lac profond

\footnotetext{
*Corresponding author: serhantarkan@gmail.com
} 


\section{Introduction}

The high endemism and species richness of freshwater ecosystems results in introductions of non-native species being a significant conservation issue, especially as the costs of controlling freshwater invasions are considerable (Britton et al., 2011). Efforts to manage invasions should involve species-specific risk assessments that evaluate whether the species will establish, disperse and cause impact, according to the available empirical evidence (Copp et al., 2016). Where assessments are inhibited by a lack of empirical data for a species in its invasive range (Roy et al., 2017), they can utilise ecological information derived from the species' native range (Ribeiro et al., 2008).

The Ponto-Caspian (P-C) region is a major source area for invasive gobies (Roche et al., 2013). P-C gobies have colonized many freshwater ecosystems around the world, including the upper and middle Danube River in Europe (Jepsen et al., 2008), and the North American Great Lakes (Brown and Stepien, 2009). Introductions have been primarily via ship ballast water (Corkum et al., 2004; Roche et al., 2013). The Western tubenose goby Proterorhinus semilunaris (Heckel, 1837) is a strong example of a P-C goby that has been introduced into a number of new regions. Initial introductions to North America were into the Laurentian Great Lakes (St. Clair River) in 1990 via ballast water (Jude et al., 1992). In Europe, initial introductions were to the Danube part of the Czech Republic in 1994, most likely via their use as angling bait (Lusk and Halačka, 1995). In both continents, the species remains spatially restricted with, for example, their North American distribution mainly limited to some Great lakes (e.g. Lake St. Clair, Lake Erie and western Lake Superior) (Vanderploeg et al., 2002). Their ecological impacts relate to their predation of benthic macro-invertebrates that potentially have top-down effects (Vašek et al., 2014; Mikl et al., 2017).

The small bodied gobiid, P. semilunaris is typically found in shallow rocky substrates (Jude and DeBoe, 1996), where its diet is invertebrate based (e.g. chironomid larvae and zooplankton) (Adámek et al., 2007). There is limited information available on their life history traits in freshwaters, with most native studies conducted in marine or estuarine environments, including the Azov and Caspian seas (Ragimov, 1986; Smirnov 1986; Harka and Farkas, 2006). Indeed, there is only a single study available on their somatic growth in their native range (Lake Tisa, Eastern Hungary; Harka and Farkas, 2006). There are, however, other biological data available in both ranges, including sex ratios, weight-length (WL) relationships and diet (e.g. Tarkan et al., 2006, 2009; Všetičková et al., 2014).

Invasion risk assessments have predicted that $P$. semilunaris has moderately high invasiveness in the Balkans (Simonović et al., 2013) and medium invasion potential in Turkey (Tarkan et al., 2017), Finland (Puntila et al., 2013) and the Murray-Darling basin, Australia (Vilizzi and Copp, 2013). Their potential to rapidly colonise novel environments stems from traits including a prolonged spawning period and batchspawning behaviours (e.g. Valová et al., 2015). Some studies also highlight their potential to compete with native species (especially juveniles) for food resources (Kocovsky et al., 2011; Vštičková et al., 2014). However, there remain considerable gaps in knowledge on their interactions and autecology from both their native and non-native ranges.

Given the potentially high utility of ecological data for non-native species from their native range to inform invasion risk assessments, and to overcome the knowledge gaps in P. semilunaris ecology, the aim here was to quantify a range of ecological and biological characteristics across three lakes in their native range. Objectives were to evaluate their life history traits across the lakes (age structure, somatic growth, reproductive characteristics), and discuss these in the context of their potential invasiveness and the commensurate invasion management actions.

\section{Materials and methods}

\subsection{Study sites}

One shallow (Uluabat) and two deep (İznik and Sapanca) natural lakes located in the Marmara Region (north-west of Anatolia, Turkey) were sampled for P. semilunaris (Fig. 1). The main physico-chemical and morphological characteristics of the lakes are presented in Table 1. The lakes have a diverse ichthyofaunal that is dominated by fishes of the Cyprinidae family (Geldiay and Balı, 2009). Other gobiid fishes are present, including monkey goby Neogobius fluviatilis, round goby Neogobius melanostomus and Caucasian dwarf goby Knipowitchia caucasica. Piscivores include Northern pike Esox lucius and wels catfish Silurus glanis. Introduced fishes include gibel carp Carassius gibelio and pumpkinseed Lepomis gibbosus. The presence in the lakes of P. semilunaris was recorded in the first ichthyofaunal studies in the studied lakes (e.g. Numann, 1958) and is considered as a native fish species.

Lake İznik is a deep, tectonic, eutrophic lake. Fish were sampled from its littoral shallow habitats that had substrates of fine sand and gravel, and with emergent and submerged macrophytes. Lake Sapanca is also a deep tectonic lake that suffers from water level fluctuations and high nutrient inputs, that results in frequent algal blooms. Its $P$. semilunaris population inhabits areas around confluences the with inflowing streams. Samples were thus collected mainly from five inflowing streams, where substrates were of fine sand, coarse gravel and small rocks. The flow regimes were variable, and widths were to $6 \mathrm{~m}$ and depths to $2 \mathrm{~m}$. However, because of the low number of fish captured in each of the streams of Lake Sapanca, their fish samples were combined together for the purposes of data analysis. Lake Uluabat is a shallow (mean depth $\sim 2.5 \mathrm{~m}$ ), eutrophic lake that has a RAMSAR designation due to migratory birds. It also suffers from the adverse impacts of abstraction, and domestic and industrial waste discharges (Arslan et al., 2010). Samples of $P$. semilunaris population were collected from littoral areas, where abundant submerged macrophytes were present over a substrate of fine sand and large rocks (Fig. 1).

\subsection{Sample collection and processing}

All samples of $P$. semilunaris were collected by electrofishing (SAMUS-725G). Sampling was completed from August 2014 to January 2016 on a quarterly basis: August (summer), November (autumn), January (winter) and April/May (spring). In each lake, the sampled areas were 


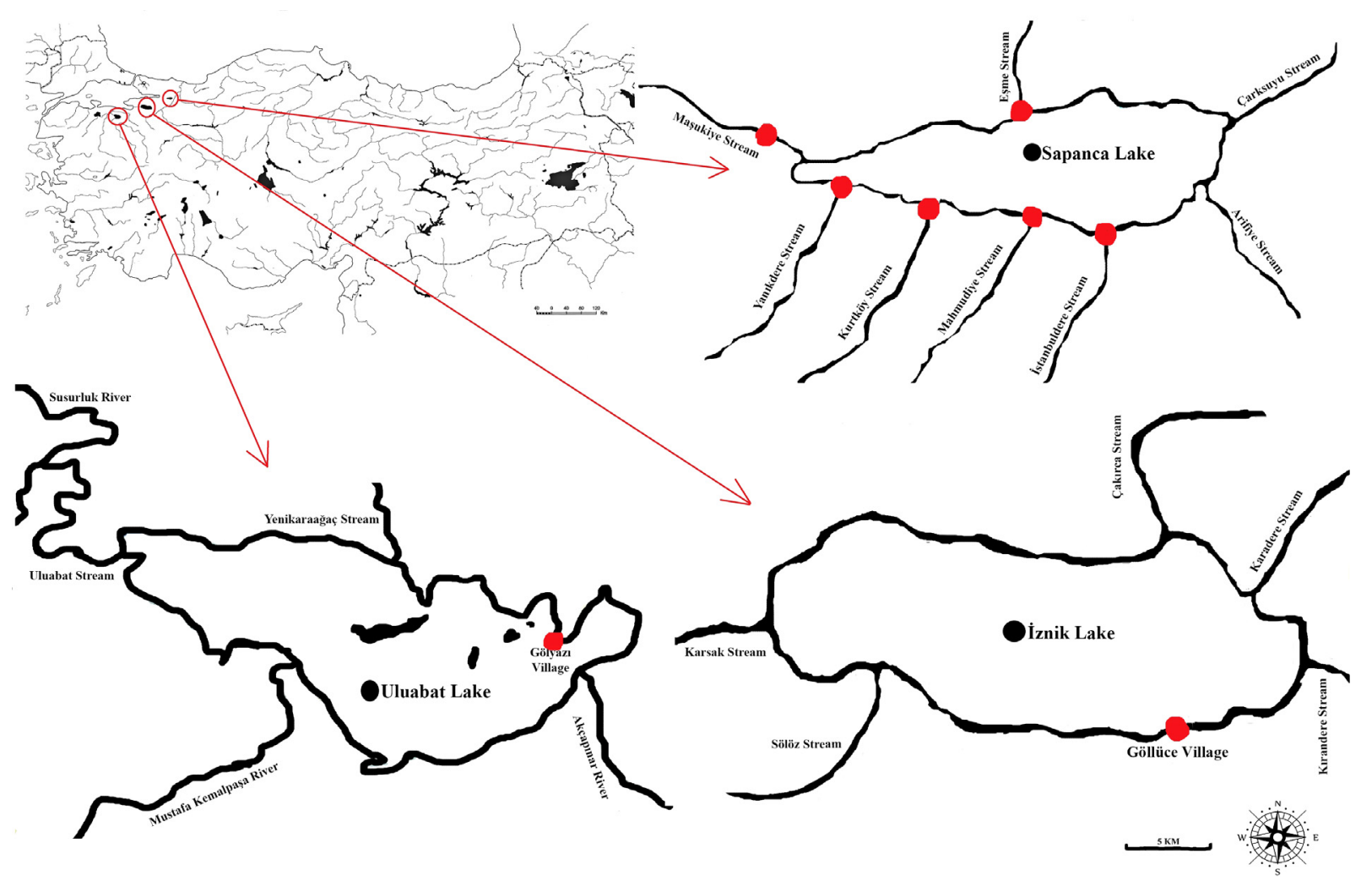

Fig. 1. Sampling areas (marked by red) where P. semilunaris were collected in Marmara region (northwest Turkey).

Table 1. Latitude (Lat), longitude (Lon), surface area (SA, $\mathrm{km}^{2}$ ), altitude (Alt, $\mathrm{m}$ ), minimum (Min), maximum (Max) and mean temperature $\left({ }^{\circ} \mathrm{C}\right)$, mean and maximum depth $(\mathrm{m}), \mathrm{pH}$, dissolved oxygen $\left(\mathrm{DO}, \mathrm{mg}^{-1}\right)$, electrical conductivity $\left(\mathrm{EC}, \mu \mathrm{S} \mathrm{cm}^{-1}\right)$ and total phosphorus $\left(\mathrm{TP}, \mu \mathrm{g}^{-1}\right.$ ) of three lakes in the Marmara Region of Turkey where P. semilunaris were sampled (Karakuş et al., 2018; Tarkan et al., 2018).

\begin{tabular}{|c|c|c|c|c|c|c|c|c|c|c|c|c|c|}
\hline \multirow[b]{2}{*}{ Lake } & \multirow[b]{2}{*}{ Lat } & \multirow[b]{2}{*}{ Lon } & \multirow[b]{2}{*}{ SA } & \multirow[b]{2}{*}{ Alt } & \multicolumn{3}{|c|}{ Temperature } & \multicolumn{2}{|c|}{ Depth } & \multirow[t]{2}{*}{$\mathrm{pH}$} & \multirow[t]{2}{*}{ DO } & \multirow[t]{2}{*}{ EC } & \multirow[t]{2}{*}{ TP } \\
\hline & & & & & Min & Max & Mean & Mean & Max & & & & \\
\hline İznik & $40^{\circ} 26^{\prime}$ & $29^{\circ} 32^{\prime}$ & 313 & 85 & 7.2 & 28.4 & 16.4 & 40.0 & 80.0 & 8.4 & 7.4 & 995 & 21 \\
\hline Sapanca & $40^{\circ} 42^{\prime}$ & $30^{\circ} 15^{\prime}$ & 47 & 30 & 8.4 & 27.5 & 15.8 & 26.0 & 55.0 & 8.9 & 9.4 & 253 & 12 \\
\hline Uluabat & $40^{\circ} 10^{\prime}$ & $28^{\circ} 35^{\prime}$ & 136 & 9 & 4.1 & 28.9 & 18.1 & 2.5 & 4.5 & 8.3 & 8.0 & 553 & 179 \\
\hline
\end{tabular}

approximately $200 \mathrm{~m}$ long, $3 \mathrm{~m}$ wide and up to $1.5 \mathrm{~m}$ in deep. Where sampling was also completed in streams, this started at the confluence with the lake and extended for $200 \mathrm{~m}$ upstream. Due to the low number of specimens caught $(<5)$ in winter (January), all of the winter samples were omitted from further analyses. All lakes and streams were sampled over 3 to 4 days on each sampling occasion, with areas sampled for a fixed time for standardisation $(30 \mathrm{~min})$. Following capture, the $P$. semilunaris specimens were euthanized (anaesthetic overdose; 2-phenoxyethanol) and then transported to the laboratory in iced water.

In the laboratory, the fish were defrosted, measured (total length, TL; to $1 \mathrm{~mm}$ ) and 10 scales removed from the area between the lateral line and dorsal fin, and stored for subsequent ageing. Individuals were then dissected and weighed (eviscerated mass, EW, to $0.01 \mathrm{~g}$ ). Sex determination was from gonads, where females with ovaries containing yolked eggs and males with distinguishable testes were classified as mature. Ovaries were weighed to $0.001 \mathrm{~g}$. For fecundity estimates, sub-samples were taken from the anterior, middle, and posterior portions of each ovarian lobe and fixed (3.6\% buffered formaldehyde).

Fish ages were determined from the scales by counting their annuli from scale impressions on acetate strips (10 scales per specimen) on a micro-projector (magnification: $\times 48$ ). Two operators independently completed the age determinations, who had no prior biological knowledge of the fish. Where age estimates differed, a final determination was made and the sample was rejected if disagreement remained. In combination with regenerated scales, $10.2 \%$ of all fish were removed from the ageing dataset, with 272 individual ages retained. Annuli distances were measured along the antero-posterior axis from 
the best representative scale focus of each fish (Bagenal and Tesch, 1978). Fecundity and egg diameter (ED) estimates were made from the ovarian sub-samples from fish collected in spring (pre-spawning period) by using a stereomicroscope ( $n=50$ fish per lake). EDs were measured for 100 randomly chosen oocytes per female using an ocular micro-meter.

\subsection{Data analysis}

Catch per unit effort (CPUE) was used as an indicator of $P$. semilunaris abundance, measured as the number of sampled individuals captured in $30 \mathrm{~min}$ in the $200-\mathrm{m}$ length of lake shoreline (for İznik and Uluabat) or bank-side (for Lake Sapanca). Mean lengths-at-age (LaA) were assessed by backcalculation using the Fraser-Lee method (Francis, 1990): $L_{t}=c+\left(\mathrm{TL}_{c}-c\right)\left(S_{t} / R\right)$, where $L_{t}$ is the TL when annulus $t$ was formed, $\mathrm{TL}_{c} \mathrm{TL}$ at capture, $S_{t}$ the distance from scale focus to the annulus $t, R$ the scale radius, and $c$ is the intercept on the length axis from the linear relationship of TL versus scale radius $\left(\mathrm{TL}=8.33 \times R+12.60, r^{2}=0.67, P<0.01 ; n=272\right)$. Thus, the overall intercept $(c)$ value $(12.60 \mathrm{~mm})$ acted as a 'weighting factor' to reduce bias resulting from differences in the size distributions of the populations. WL relationships were determined from $W=a \mathrm{TL}^{b}$, where $a$ and $b$ are the regression parameters. The $95 \%$ confidence limits of $b$ indicated whether there was deviation from $b=3.0$. Fitting of WL relationships was in R v.3.4.0 using libraries 'FSA' and 'nlstools' (Ogle, 2017).

Variation in body condition due to size differences was measured using the relative body condition (RC) formula of Le Cren (1951): $\mathrm{RC}=\mathrm{EW} / E_{W}$, where $\mathrm{EW}$ is the actual weight of the individual and $E_{W}$ is the expected weight from the WL relationship. RC values $>1$ or $<1$ indicate that the individual is in better/worse condition than the other fish in the same TL range. The index requires populations to be sampled at the same time of year, region and similar stage of lifespan (Knaepkens et al., 2002). Thus, analyses were conducted separately for each seasonal sampling and comparisons were made among the lakes. For within lake and comparisons among the seasons, Fulton condition factor (FC) was used, expressed as $\mathrm{FC}=\left(\mathrm{EW} / \mathrm{TL}^{3}\right) \times 100,000$ (Bagenal and Tesch, 1978). In both indices, EW that is free from gonad mass and gut content was used to avoid bias (Masó et al., 2016).

Mean age at maturity (AaM) was calculated from the percentage of mature males and females in each age-class using the formula:

$$
\mathrm{AaM}=\sum^{A_{\max }} A\left[M_{A}-M_{(A-1)}\right]
$$

where $A$ is the age in years, $M_{A}$ the proportion (from 0 to 1 ) of mature fish at age $A$, and $A_{\max }$ is the maximum age in the fish sample. A modified version of this formula $(10 \mathrm{~mm} \mathrm{TL}$ intervals in place of age-classes; Trippel and Harvey, 1987) was used to calculate mean TL at maturity (LaM). Absolute fecundity (AF) estimates of female $P$. semilunaris were determined gravimetrically as: $\mathrm{AF}=\mathrm{GW} \times D$, where $\mathrm{AF}$ is the number of mature oocytes spawned by a female in a single spawning, GW is the weight of ovary, and $D$ is the density or the number of mature oocytes per $g$ of ovarian tissue. Relative fecundity ( $R F=$ number of oocytes $\mathrm{g}^{-1}$ of female) was calculated as $\mathrm{RF}=\mathrm{AF} / \mathrm{EW}$ (Bagenal and Tesch, 1978). The gonadosomatic index (GSI) was calculated from both males and females for each population as: $\mathrm{GSI}=(\mathrm{GW} /(\mathrm{EW}-\mathrm{GW})) \times$ 100 (Wootton, 1990).

\subsection{Statistical analyses}

Differences in the sex ratio between males and females from unity $(1: 1)$ were tested using chi-squared $\left(\chi^{2}\right)$ goodness of fit. Permutational univariate analysis of variance (PERANOVA) tested the significance of differences of back-calculated LaA, mean CPUE, $b$, TL, $W, \mathrm{RC}, \mathrm{FC}$, GSI, $\mathrm{ED}, \mathrm{AF}$ and $\mathrm{RF}$ of $P$. semilunaris among the lakes. CPUE (separately with lakes and seasons), TL, $W, b$ and ED (with lakes) were based on a one fixed-factor design, whereas a twoway factorial design for AF and RF (with EW and lakes) and LaA (with age and lakes), and a three-factor design for GSI (with EW, lakes and seasons), RC and FC (with TL, lakes and seasons) were employed, all fixed and crossed. In each case, following normalisation of the data, a Euclidean dissimilarity measure produced a distance matrix that was subjected to 9999 permutations of the raw data with statistically significant effects for the main and interaction effects followed by a posteriori pairwise comparisons $(\alpha=0.05)$. Statistical analyses were carried out in PERMANOVA+ v1.0.1 for PRIMER v6 (Anderson et al., 2008). The use of PERMANOVA versus traditional parametric analysis of variance (ANOVA) is advantageous as the stringent assumptions of normality and homoscedasticity in the data are substantially relaxed in PERMANOVA, enabling its use with real-world ecological data sets (Anderson and Robinson, 2001).

Some other gobiid species (e.g.N. melanostomus and $N$. fluviatilis) have males with greater LaAs than females (e.g. Kornis et al., 2012). However, here, lake-specific PERMANOVA models found no significant effect of sex on LaA, RC, TL and $W$; similarly, the effect of year on the parameters was not significant $\left(F^{\#}\right.$ and $P$ ranged from 0.02 to 1.36 and 0.26 to 0.84 , respectively). Thus, sex and year data for these analyses were combined. For growth analyses, von Bertalanffy growth functions were not possible to fit, as LaA values had not reached the asymptote, with linear relationships with age evident in each lake.

\section{Results}

\subsection{Sample sizes, CPUE, sex ratio and body size}

In total, 276 P. semilunaris were collected from the streams of Lake Sapanca, 172 from Lake Uluabat and 128 from Lake İznik (Tab. 2). Fish lengths varied between 20 and $73 \mathrm{~mm}$ (Tab. 2), with similar length distributions across the lakes (Fig. 2). Seasonal differences in CPUE were significant, being highest in summer for Uluabat $\left(F_{2.18}=2.97, P^{\#}<0.05\right.$, $\#=$ permutational $)$ and in autumn for İznik $\left(F_{2.18}=2.51\right.$, $\left.P^{\#}<0.05\right)$. Although not significant, summer CPUE in İznik and Sapanca was higher than in spring (Fig. 3).

Sex ratios varied between the lakes. It was significantly female dominated in Lake İznik $\left(\mathrm{F}: \mathrm{M}=1.8: 1.0, \chi^{2}=6.31\right.$; $P=0.01$ ), but was relatively equal in both Lake Uluabat 
Table 2. (A) Number of specimens (n) that could be sexed (immature specimens were left out), minimum (Min), maximum (Max), mean and standard deviation (SD) of total length (TL) and weight (W) of male (M) and female (F) P. semilunaris from İznik, Uluabat and Sapanca lakes. (B) Parameter estimates (with 95\% lower and upper confidence intervals: LCI and UCI, respectively) for the weight-length (WL) relationships for P. semilunaris in İznik, Uluabat and Sapanca lakes. The data of Lake Sapanca are mean values of the five sampled streams flowing into the Lake.

\begin{tabular}{|c|c|c|c|c|c|c|c|c|c|}
\hline \multicolumn{10}{|c|}{ A } \\
\hline \multirow[b]{2}{*}{ Lakes } & \multirow[b]{2}{*}{$n$} & \multicolumn{4}{|c|}{$\mathrm{TL}$} & \multicolumn{4}{|c|}{$W$} \\
\hline & & Min & Max & Mean & SD & Min & $\operatorname{Max}$ & Mean & $\mathrm{SD}$ \\
\hline İznik (M) & 30 & 25 & 73 & 45.13 & 1.34 & 0.14 & 4.75 & 1.27 & 1.20 \\
\hline İznik (F) & 53 & 23 & 67 & 54.85 & 0.99 & 0.15 & 4.24 & 1.13 & 1.00 \\
\hline Uluabat (M) & 35 & 23 & 66 & 44.71 & 1.13 & 0.13 & 3.26 & 1.31 & 0.93 \\
\hline Uluabat (F) & 48 & 24 & 58 & 42.69 & 0.85 & 0.12 & 2.62 & 1.01 & 0.64 \\
\hline Sapanca (M) & 79 & 21 & 72 & 44.20 & 1.12 & 0.09 & 4.73 & 1.30 & 1.07 \\
\hline Sapanca (F) & 105 & 20 & 70 & 45.44 & 1.01 & 0.09 & 4.00 & 1.22 & 0.82 \\
\hline \multicolumn{10}{|l|}{ B } \\
\hline \multicolumn{10}{|l|}{$\mathrm{WL}$} \\
\hline Parameter & & \multicolumn{2}{|l|}{ Estimate } & \multicolumn{2}{|c|}{$\mathrm{SE}$} & \multicolumn{3}{|c|}{ LCI } & $\mathrm{UCI}$ \\
\hline \multicolumn{10}{|l|}{ İznik } \\
\hline$a$ & & \multicolumn{2}{|l|}{0.007} & \multicolumn{2}{|c|}{0.075} & \multicolumn{3}{|c|}{-0.142} & 0.155 \\
\hline$b$ & & \multicolumn{2}{|l|}{3.217} & \multicolumn{2}{|c|}{0.054} & \multicolumn{3}{|c|}{3.110} & 3.325 \\
\hline \multicolumn{10}{|l|}{ Uluabat } \\
\hline$a$ & & \multicolumn{2}{|l|}{0.006} & \multicolumn{2}{|c|}{0.00001} & \multicolumn{3}{|c|}{-0.080} & 0.200 \\
\hline$b$ & & \multicolumn{2}{|l|}{3.415} & \multicolumn{2}{|c|}{0.051} & \multicolumn{3}{|c|}{3.314} & 3.517 \\
\hline \multicolumn{10}{|l|}{ Sapanca } \\
\hline$a$ & & \multicolumn{2}{|l|}{0.009} & \multicolumn{2}{|c|}{-0.052} & \multicolumn{3}{|c|}{-0.013} & 0.019 \\
\hline$b$ & & \multicolumn{2}{|l|}{3.153} & \multicolumn{2}{|c|}{0.037} & \multicolumn{2}{|r|}{3.080} & & 3.225 \\
\hline
\end{tabular}

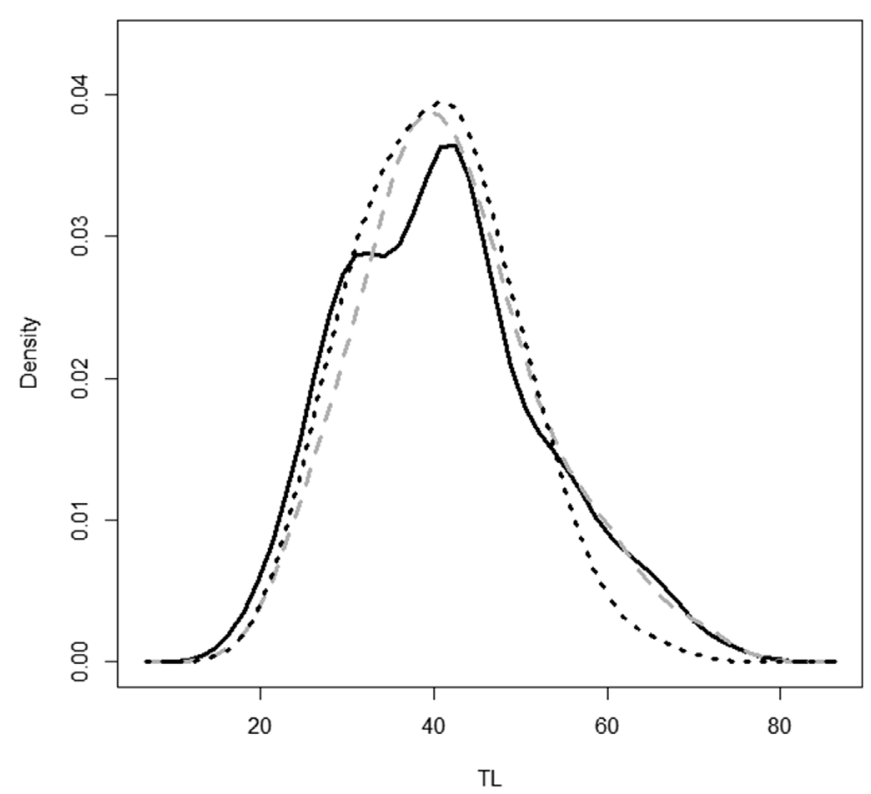

Fig. 2. Probability density plots (Kernel density estimation) of P. semilunaris length distributions from Lake Uluabat (solid black), Lake Sapanca (solid grey) and Lake İznik (dashed black).

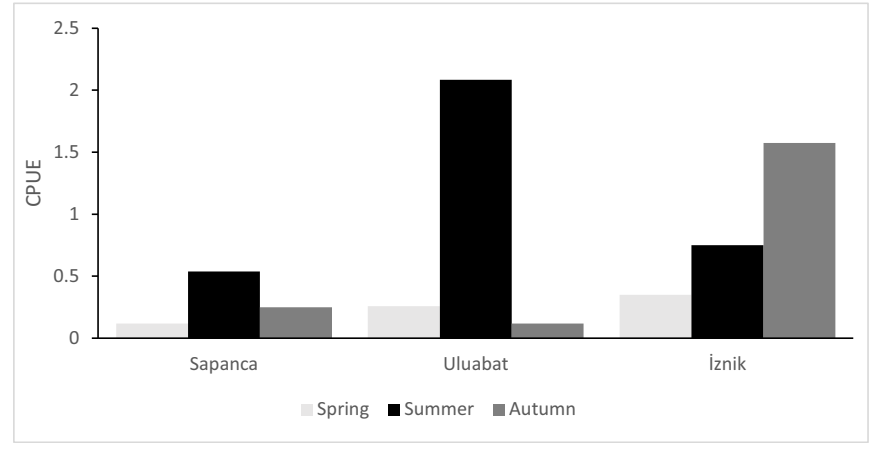

Fig. 3. Catch per Unit Effort (CPUE) of P. semilunaris from the streams of Lake Sapanca (upper) and all studied lakes (lower) by each season.

(1.4:1.0, $\left.\chi^{2}=2.02 ; P=0.16\right)$ and Lake Sapanca (1.4:1.0, $\left.\chi^{2}=1.33 ; P=0.06\right)$. There was seasonal variation, with samples from İznik being female dominated in spring (8.0:1.0, $\left.\chi^{2}=10.89 ; P<0.01\right)$. Samples from Lake Sapanca were male dominated in summer $\left(0.5: 1.0, \chi^{2}=5.84 ; P=0.02\right)$, but female dominated in autumn (6.2:1.0, $\chi^{2}=18.78$; $P<0.0001)$. In Lake Uluabat, seasonal sex ratios were not significantly different $\left(P_{s}>0.05\right)$. 
Table 3. For P. semilunaris (all individuals combined) from three lakes in the Marmara region, number of specimens ( $n$ ), mean total length (TL) in $\mathrm{mm}$ at capture, mean back-calculated lengths at age, standard error (SE), and mean annual growth increments using the scale radius to TL regression equation.

\begin{tabular}{|c|c|c|c|c|c|c|c|c|c|c|c|c|c|}
\hline \multirow{3}{*}{ Lakes } & \multicolumn{13}{|c|}{ Back-calculated body lengths at age } \\
\hline & \multirow[b]{2}{*}{$n$} & \multicolumn{2}{|c|}{ TL at capture } & \multicolumn{2}{|c|}{ Age 1} & \multicolumn{2}{|c|}{ Age 2} & \multicolumn{2}{|c|}{ Age 3} & \multicolumn{2}{|c|}{ Age 4} & \multicolumn{2}{|c|}{ Age 5} \\
\hline & & TL & SE & $\mathrm{TL}$ & SE & $\mathrm{TL}$ & SE & $\mathrm{TL}$ & SE & TL & SE & $\mathrm{TL}$ & SE \\
\hline \multicolumn{14}{|l|}{ İznik } \\
\hline 2015 & 14 & 34.10 & 0.18 & 33.68 & 0.07 & & & & & & & & \\
\hline 2014 & 20 & 47.00 & 0.17 & 33.53 & 0.07 & 43.68 & 0.08 & & & & & & \\
\hline 2013 & 11 & 50.10 & 0.24 & 30.80 & 0.12 & 41.25 & 0.17 & 50.09 & 0.24 & & & & \\
\hline 2012 & 8 & 61.30 & 0.20 & 31.50 & 0.14 & 42.28 & 0.21 & 51.94 & 0.22 & 61.25 & 0.20 & & \\
\hline \multicolumn{4}{|c|}{ Mean back-calculated TL at age } & 32.37 & & 42.40 & & 51.01 & & 61.25 & & & \\
\hline \multicolumn{4}{|c|}{ Mean TL increment (mm) } & & 10.03 & & 8.61 & & 10.24 & & & & \\
\hline \multicolumn{14}{|c|}{ Uluabat } \\
\hline 2015 & 10 & 31.40 & 0.13 & 27.78 & 0.86 & & & & & & & & \\
\hline 2014 & 16 & 37.20 & 0.13 & 27.97 & 0.06 & 31.06 & 0.24 & & & & & & \\
\hline 2013 & 21 & 46.70 & 0.12 & 29.17 & 0.07 & 38.99 & 0.10 & 46.71 & 0.12 & & & & \\
\hline 2012 & 7 & 52.70 & 0.17 & 27.44 & 0.06 & 35.85 & 0.08 & 45.21 & 0.12 & 52.71 & 0.17 & & \\
\hline \multicolumn{4}{|c|}{ Mean back-calculated TL at age } & 28.09 & 0.37 & 35.30 & 2.30 & 45.96 & 0.75 & 52.71 & - & & \\
\hline \multicolumn{4}{|c|}{ Mean TL increment (mm) } & & 7.21 & & 10.66 & & 6.75 & & & & \\
\hline \multicolumn{14}{|c|}{ Sapanca } \\
\hline 2015 & 15 & 26.92 & 0.19 & 25.60 & 0.11 & & & & & & & & \\
\hline 2014 & 42 & 37.19 & 0.11 & 27.18 & 0.04 & 34.67 & 0.07 & & & & & & \\
\hline 2013 & 74 & 43.51 & 0.08 & 27.38 & 0.04 & 35.13 & 0.05 & 41.64 & 0.07 & & & & \\
\hline 2012 & 22 & 55.13 & 0.17 & 29.32 & 0.05 & 37.49 & 0.07 & 46.43 & 0.09 & 54.72 & 0.12 & & \\
\hline 2011 & 12 & 59.91 & $0.1 \times 7$ & 27.28 & 0.12 & 32.65 & 0.18 & 39.99 & 0.24 & 47.78 & 0.27 & 54.99 & 0.25 \\
\hline \multicolumn{4}{|c|}{ Mean back-calculated TL at age } & 27.35 & 0.59 & 34.99 & 0.99 & 42.69 & 1.92 & 51.25 & 3.47 & 54.99 & - \\
\hline \multicolumn{4}{|c|}{ Mean TL increment (mm) } & & 7.64 & & 7.70 & & 8.56 & & 3.74 & & \\
\hline
\end{tabular}

Across the three lakes, there were minimal differences in mean total length $\left(F_{2,571}=1.98, P^{\#}>0.05\right)$, but there were significant differences in mean weight $\left(F_{2.575}=3.39, P^{\#}<0.05\right)$. The fish from Lake Sapanca and Lake İznik were significantly heavier than from Lake Uluabat $\left(t^{\#}=2.44, P^{\#}<0.05 ; t^{\#}=2.60\right.$, $\left.P^{\#}<0.05\right)$ (Tab. 2).

\subsection{Weight-length relationship, condition and growth}

In each lake, estimated values of $b$ (as $95 \% \mathrm{CI}$ ) in the weight-length relationship were all above 3.0, indicating positive allometry (Tab. 2). $b$ was significantly higher in Lake Uluabat than Lake Sapanca and Lake İznik $\left(F^{\#}=23.12\right.$, $P^{\#}<0.01$ ), but differences between Lake Sapanca and Lake İznik were not significant $\left(F^{\#}=0.74, P^{\#}>0.05\right)$.

The oldest aged fish was 5 years old in the streams Lake Sapanca, where the lowest LaA values were recorded (Tab. 3). The highest LaA were from Lake İznik. Between lake differences in LaA were significant (lake; $F_{2260}=28.45$, $P^{\#}<0.001$, lake $\times$ age interaction; $\left.F_{6.260}=5.57, P^{\#}<0.001\right)$ (Tab. 4). The significant differences included higher growth increments at ages 1, 2 and 4 years in Lake İznik than Uluabat (for age $1 ; t^{\#}=4.96, P^{\#}<0.001$, age $2 ; t^{\#}=5.29, P^{\#}<0.001$, age $4 ; t^{\#}=3.49, P^{\#}<0.01$ ), and higher in Lake İznik than Lake Sapanca (for age $1 ; t^{\#}=5.01, P^{\#}<0.001$, age $2 ; t^{\#}=7.29$, $P^{\#}<0.001$, age $4 ; t^{\#}=2.60, P^{\#}<0.05$ ).
There was significant variation in the relative condition of $P$. semilunaris between the lakes $\left(F_{4.244}=2.83, P^{\#}<0.05\right)$. Specifically, significant differences were in autumn, with fish Lake Sapanca having higher RC values than Lake Uluabat $\left(t^{\#}=3.43, P^{\#}<0.05\right)$, and in spring, where fish in Lake İznik had significantly lower relative condition than Lake Uluabat $\left(t^{\#}=4.66, P^{\#}<0.001\right)$ and the Sapanca $\left(t^{\#}=4.48, P^{\#}<0.05\right)$ (Tab. 5). For Fulton's condition, no significant differences were detected between seasons for the lakes $\left(F_{4,244}=0.96\right.$, $\left.P^{\#}>0.05\right)$ (Tab. 5).

\subsection{Reproduction and life history traits}

The minimum total lengths and ages of mature P. semilunaris were: Lake İznik: female $40 \mathrm{~mm}$ and 2 years, male $33 \mathrm{~mm}$ and 3 years; Lake Uluabat: female $42 \mathrm{~mm}$ and 3 years, male $35 \mathrm{~mm}$ and 3 years; and Lake Sapanca: females $38 \mathrm{~mm}$ and 3 years, males $37 \mathrm{~mm}$ and 3 years (Tab. 6). Seasonal GSI data were generally similar between the lakes $\left(F_{219,254}=2.98, P^{\#}=0.10\right.$, and its interaction with lake: $\left.F_{1,254}=0.07, P^{\#}=0.94\right)$. The highest values occurred in spring and summer, suggesting a prolonged spawning period (Fig. 4). Females generally had significantly higher GSI values than males $\left(P^{\nexists}<0.05\right)$ in the spawning period.

Differences in EDs between the lakes were not significant $\left(F_{2,147}=1.59, P^{\#}=0.80\right)($ Tab. 6). There were no significant 
N. Top et al.: Knowl. Manag. Aquat. Ecosyst. 2018, 419, 48

Table 4. PERMANOVA results for total length at age among the three studied lakes (Uluabat, Sapanca, İznik).

\begin{tabular}{|c|c|c|c|c|c|}
\hline & $d f$ & MS & $F^{\#}$ & $t^{\#}$ & $P^{\#}$ \\
\hline Age & 3 & 41.27 & 128.85 & & 0.0001 \\
\hline Lake & 2 & 9.11 & 28.45 & & 0.0001 \\
\hline Uluabat $v s$. Sapanca & & & & 0.38 & 0.7044 \\
\hline Uluabat $v s$. İznik & & & & 5.91 & 0.0001 \\
\hline Sapanca vs. İznik & & & & 7.57 & 0.0001 \\
\hline Age $\times$ lake & 6 & 0.93 & 2.90 & & 0.0081 \\
\hline \multicolumn{6}{|l|}{ Age 1} \\
\hline Uluabat $v$ s. Sapanca & & & & 1.44 & 0.1629 \\
\hline Uluabat $v s$. İznik & & & & 4.96 & 0.0001 \\
\hline Sapanca vs. İznik & & & & 5.01 & 0.0001 \\
\hline \multicolumn{6}{|l|}{ Age 2} \\
\hline Uluabat $v s$. Sapanca & & & & 1.90 & 0.0599 \\
\hline Uluabat $v s$. İznik & & & & 5.29 & 0.0001 \\
\hline Sapanca vs. İznik & & & & 7.29 & 0.0001 \\
\hline \multicolumn{6}{|l|}{ Age 3} \\
\hline Uluabat $v$ s. Sapanca & & & & 3.26 & 0.0016 \\
\hline Uluabat vs. İznik & & & & 1.38 & 0.1842 \\
\hline Sapanca vs. İznik & & & & 3.93 & 0.0004 \\
\hline \multicolumn{6}{|l|}{ Age 4} \\
\hline Uluabat $v s$. Sapanca & & & & 0.72 & 0.4791 \\
\hline Uluabat vs. İznik & & & & 3.49 & 0.0080 \\
\hline Sapanca vs. İznik & & & & 2.60 & 0.0131 \\
\hline
\end{tabular}

A posteriori pairwise comparisons are given for the statistically effect of interest $\left(\alpha=0.05\right.$, in bold type). $F^{\#}=$ permutational $F$ value; $t^{\#}=$ permutational $t$-test value; $P^{\#}=$ permutational probability value; $M S=$ mean square; PERMANOVA = permutational univariate analysis of variance.

Table 5. Relative condition (RC) and Fulton's condition (FC) values of $P$. semilunaris by seasons from İznik, Uluabat and Sapanca lakes.

\begin{tabular}{|c|c|c|c|c|c|c|}
\hline \multirow[b]{2}{*}{ Lakes } & \multicolumn{2}{|c|}{ Spring } & \multicolumn{2}{|c|}{ Summer } & \multicolumn{2}{|c|}{ Autumn } \\
\hline & $\mathrm{RC}$ & $\mathrm{FC}$ & $\mathrm{RC}$ & $\mathrm{FC}$ & $\mathrm{RC}$ & $\mathrm{FC}$ \\
\hline İznik & $0.87 \pm 0.16$ & $0.59 \pm 0.12$ & $0.95 \pm 0.17$ & $0.89 \pm 0.22$ & $1.00 \pm 0.17$ & $0.73 \pm 0.11$ \\
\hline Uluabat & $1.01 \pm 0.12$ & $0.74 \pm 0.10$ & $0.99 \pm 0.11$ & $0.85 \pm 0.14$ & $0.90 \pm 0.14$ & $0.65 \pm 0.09$ \\
\hline Sapanca & $1.14 \pm 0.17$ & $0.81 \pm 0.16$ & $1.04 \pm 0.16$ & $0.88 \pm 0.17$ & $1.08 \pm 0.22$ & $0.87 \pm 0.18$ \\
\hline
\end{tabular}

differences in absolute $\left(F_{2,147}=2.33, P^{\#}=0.50\right)$ and relative $\left(F_{2,147}=1.17, P^{\#}=0.86\right)$ fecundity between the lakes (Tab. 6). However, AF was positively $(r>0.90)$ and significantly $(P<0.05)$ correlated with length and weight in all lakes (Tab. 6).

\section{Discussion}

Despite a 30-year invasion history in North America and Europe, there is a considerable knowledge gap on the environmental biology of $P$. semilunaris, especially when compared with other P-C gobiids, such as N. melanostomus (Kornis et al., 2012). To our knowledge, no study has previously aged $P$. semilunaris from hard structures, with the only ageing data from length frequency analyses (Harka and Farkas, 2006; Všetičková et al., 2014). Although maximum age and length given in these studies are similar to our results, the age structure and length at age data are considerably different to our data. This suggests that ageing of this species should be based on the analysis of hard structures, such as scales, and further studies on the age ranges and growth rates of $P$. semilunaris should be completed across their native and invasive ranges. These studies would then enable testing of age and growth data between their ranges and over environmental and latitudinal gradients. These analyses have been completed for other invasive fishes, including pumpkinseed Lepomis gibbosus (Cucherousset et al., 2009) and largemouth bass Micropterus salmoides (Britton et al., 2010).

Significant differences in LaA between the lakes suggested the growth rates of $P$. semilunaris are highly variable. In general, fish growth is indeterminate and can vary highly between populations due to a wide range of abiotic (e.g. water temperature) and biotic (e.g. food availability) factors (Beardsley and Britton, 2012). Thus, the differences in growth rates between the lakes are likely to be related to differences in their environmental conditions and/or the habitats sampled 
Table 6. Mean age at maturity (AaM, in years), mean total length (TL) at maturity (TLaM, in $\mathrm{mm}$ ), mean absolute (AF) and relative fecundity (RF), mean egg diameter (ED, in $\mathrm{mm}$ ), relationship between TL and weight $(W)$ and absolute fecundity of $P$. semilunaris from Uluabat, Sapanca and İznik lakes.

\begin{tabular}{llll}
\hline $\begin{array}{l}\text { Reproductive } \\
\text { parameters }\end{array}$ & İznik & Uluabat & Sapanca \\
\hline AaM (M) & 3.17 & 3.33 & 3.66 \\
AaM (F) & 2.58 & 3.25 & 3.54 \\
TLaM (M) & $52.70(39-73)$ & $56.70(35-66)$ & $59.80(52-72)$ \\
TLaM (F) & $42.20(38-63)$ & $48.80(44-53)$ & $49.00(36-59)$ \\
AF & $122.46 \pm 32.32$ & $154.71 \pm 36.66$ & $148.83 \pm 52.00$ \\
RF & $140.26 \pm 84.21$ & $135.39 \pm 29.58$ & $124.77 \pm 85.78$ \\
ED & $0.42 \pm 0.18$ & $0.50 \pm 0.20$ & $0.44 \pm 0.22$ \\
TL-AF & $4.0266 \mathrm{AF}^{0.0128}$ & $1.9487 \mathrm{AF}^{0.1761}$ & $1.7216 \mathrm{AF}^{0.0191}$ \\
$W$-AF & $0.5169 \mathrm{AF}^{0.0790}$ & $0.0354 \mathrm{AF}^{0.7074}$ & $0.0313 \mathrm{AF}^{0.8007}$ \\
\hline
\end{tabular}

$\mathrm{M}=$ males, $\mathrm{F}=$ females. Total length range (TL, $\mathrm{mm}$ ) of the specimens that mean fecundity and ED were calculated: Lake Uluabat $=44-53$, Lake Sapanca $=36-59$, Lake İznik $=38-57$.

(i.e. deep vs. shallow; lotic vs. lentic). These environmental differences were despite their close proximity in a relatively small geographical region (the Marmara region) and some similarities in their physical features, such as their recorded temperature, $\mathrm{pH}$ and dissolved oxygen levels. Notably, the largest lake (Lake İznik) had the fastest growth rates and Lake Sapanca had the slowest, where the latter was sampled from inflowing streams.

Compared to studies on age and growth, more studies have been completed on $P$. semilunaris reproduction, including in their native and non-native ranges. Our results revealed their reproductive characteristics did not differ significantly between the lakes, although they did differ with other studies from both distribution ranges. The apparently fast growth of $P$. semilunaris reported in other studies (i.e. Valová et al., 2015) was coincident with earlier ages at maturity (usually $<1$ year old). Conversely, we measured maturity at 2 and 3 years old, although lengths at maturity were more similar. Similarly, their spawning period was similar between our lakes and other water bodies from the native range, including in Bulgaria (Georghiev, 1966) and Hungary (Harka and Farkas, 2006) where spawning was occurring as late as August. Other studies have reported spawning was complete in June in both their native (e.g. Azov Molochnyi estuary, Yankovskiy, 1966) and non-native (Ladich and Kratochvil, 1989; Valová et al., 2015) ranges.

For fecundity, ranges of 379-628 eggs were reported for a non-native $P$. semilunaris population from the Czech Republic (Valová et al., 2015), with these estimates similar to some native populations from marine environments, such as the Caspian Sea (i.e. 354 to 714 eggs; Ragimov, 1986) and the Sea of Azov (i.e. 207 to 648 eggs; Smirnov, 1986). These estimates were higher than for our lakes, where estimates were only 123-155 eggs per female. Despite the fact that this comparison should include relative instead AF, as the latter is largely affected by the size of the specimens, our length ranges of the females analysed for fecundity were higher than those

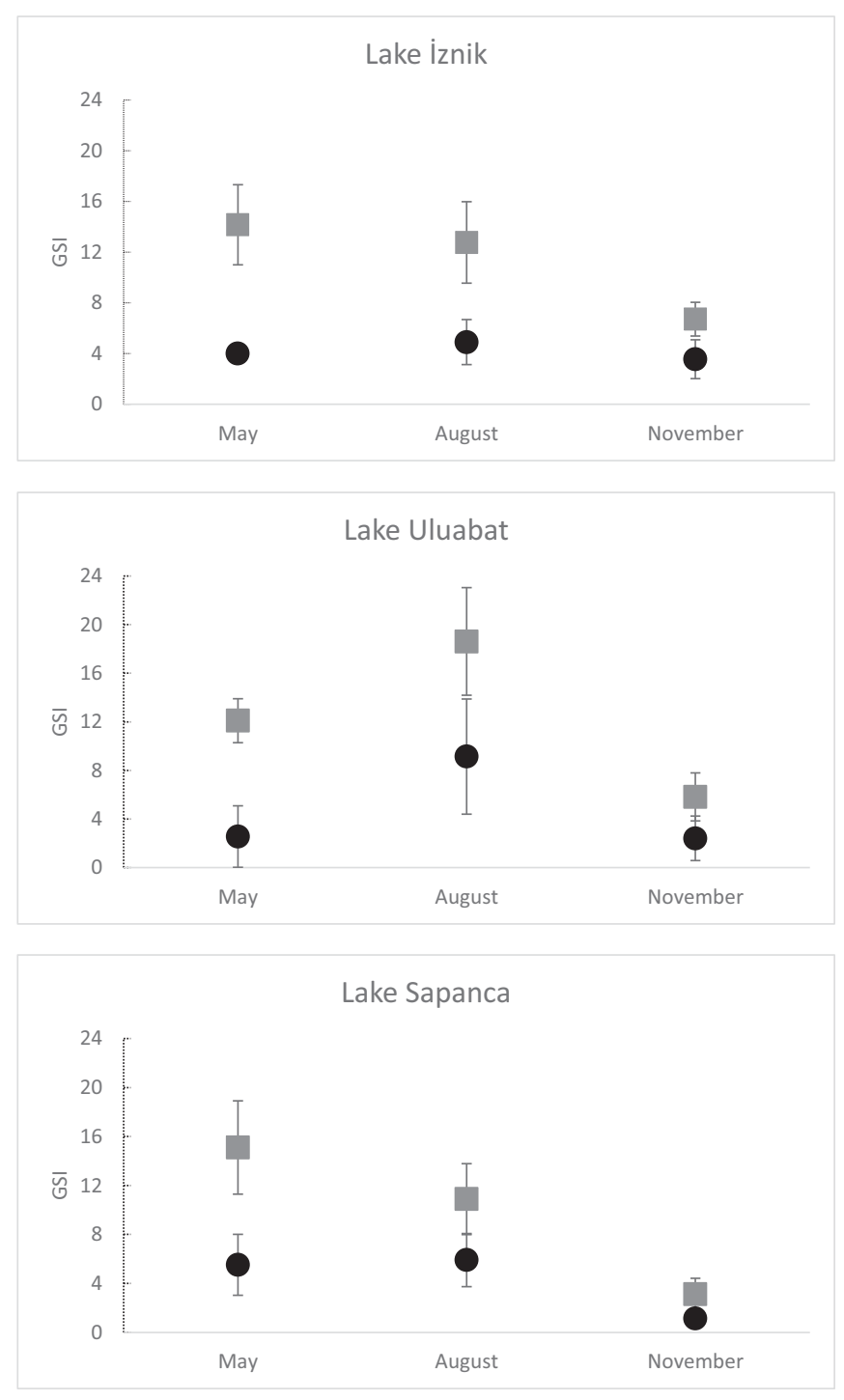

Fig. 4. Gonadosomatic Index (GSI) $\pm \mathrm{SD}$ of male (circle) and female (square) $P$. semilunaris from the lakes sampled in Marmara Region.

for the non-native population in the Czech Republic (44 to $59 \mathrm{~mm}$ TL vs. 28 to $50 \mathrm{~mm} \mathrm{SL}$ ) (Valová et al., 2015). Speculatively, the difference between our fecundity results and the other studies could relate to the higher productivity and lower species diversity of the Azov and Caspian Seas than our lakes. It might also relate to the non-native $P$. semilunaris allocating more resources to reproduction than to somatic growth to assist their establishment and invasion (e.g. Kováč et al., 2009).

In conclusion, our results suggest that $P$. semilunaris in three natural lakes in their native range had high plasticity in aspects of their life history traits, especially growth rates. As trait plasticity provides individuals with high adaptive capacity when introduced into new environments, these data suggest that this attribute should facilitate the ability of $P$. semilunaris to survive the introduction process and then establish populations in novel environments (Colautti et al., 2006). In terms of management actions, the outcomes of 
the present study emphasise the need to monitor potential further expansion of $P$. semilunaris across their nonnative range and indicate the need for a full risk assessment of their detrimental impacts on native fauna and food web structure. If high invasion risks are identified, actions and the implementation of measures to prevent the further spread and/or introduction of this species should be prioritised.

Acknowledgements. This study was supported by The Scientific \& Technological Research Council of Turkey (TÜBITAK) (Project No: 114Y009).

Conflicts of interest. The authors declare no conflict of interest.

\section{References}

Adámek Z, Andreji J, Gallardo JM. 2007. Food habits of four bottomdwelling Gobiid species at the confluence of the Danube and Hron Rivers (South Slovakia). Int Rev Hydrobiol 92: 554-563.

Anderson MJ, Robinson J. 2001. Permutation tests for linear models. Aust N Z J Stat 43: 75-88.

Anderson MJ, Gorley RN, Clarke KR. 2008. PERMANOVA+ for PRIMER: Guide to Software and Statistical Methods. Plymouth, UK: PRIMER-E Ltd.

Arslan N, Aylk Ö, Şahin Y. 2010. Diversity and structure of Chrinomidae (Diptera) limnofauna of Lake Uluabat, a Ramsar site of Turkey, and their relation to environmental variables. TurkJ Fish Aquat Sci 10: 315-322.

Bagenal TB, Tesch FW. 1978. Age and growth. In: Bagenal TB, ed. Methods for Assessment of Fish Production in Fresh Waters. Oxford, UK: IBH Handbook, Blackwell Scientific Publications, pp. 101-136.

Beardsley H, Britton JR. 2012. Contribution of temperature and nutrient loading to growth rate variation of three cyprinid fishes in a lowland river. Aquat Ecol 46: 143-152.

Britton JR, Harper DM, Oyugi DO. 2010. Is the fast growth of an equatorial Micropterus salmoides population explained by high water temperature? Ecol Freshwat Fish 19: 228-238.

Britton JR, Copp GH, Gozlan RE. 2011. Managing non-native fish in the environment. Fish Fish 12: 256-274.

Brown JE, Stepien CA. 2009. Invasion genetics of the Eurasian round goby in North America: tracing sources and spread patterns. Mol Ecol 18: 64-79.

Colautti RI, Grigorovich IA, MacIsaac HJ. 2006. Propagule pressure: a null model for biological invasions. Biol Invasions 8: 1023-1037.

Copp GH, Russell IC, Peeler EJ, Gherardi F, Tricarico E, Macleod A, Cowx IG, Nunn AD, Occhipinti-Ambrogi A, Savini D, Mumford J, Britton JR. 2016. European non-native species in aquaculture risk analysis scheme - a summary of assessment protocols and decision support tools for use of alien species in aquaculture. Fish Manag Ecol 23: 1-11.

Corkum LD, Sapota MR, Skorá KE. 2004. The round goby, Neogobius melanostomus, a fish invader on both sides of the Atlantic Ocean. Biol Invasions 6: 173-181.

Cucherousset J, Copp GH, Fox MG, Sterud E, van Kleef HH, Verreycken H, Zahorska E. 2009. Life history traits and potential invasiveness of introduced pumpkinseed Lepomis gibbosus populations in northwestern Europe. Biol Invasions 11: 2171-2108.

Francis RICC. 1990. Back-calculation of fish length: a critical review. J Fish Biol 36: 883-902.
Geldiay R, Balık S. 2009. The Freshwater Fishes of Turkey. Ege Üniversitesi Fen Fakültesi Kitaplar Serisi, İzmir, Turkey, p. 519. Georghiev JM. 1966. Composition d'espèce et caractéristique des Gobiides (Piscea) en Bulgaria. In: Proceedings of the Research Institute of Fisheries and Oceanography, Varna 7, pp. 159-228.

Harka A, Farkas J. 2006. Growth and spawning period of the tubenose goby (Proterorhinus marmoratus (Pallas, 1811) in Lake Tisa (Eastern Hungary). Oesterreichs Fischerei 59: 194-201.

Jepsen N, Wiesner C, Schotzko N. 2008. Fish. In: Liška I, Wagner F, Slobodník J, eds. Technical Report with Results From the Fish Sampling and Analyses from the Joint Danube Survey 2007, ICPDR, Vienna, pp. 72-81.

Jude DJ, Reider RH, Smith GR. 1992. Establishment of Gobiidae in the Great Lakes basin. Can J Fish Aquat Sci 49: 416-421.

Jude DJ, DeBoe SF. 1996. Possible impact of gobies and other introduced species on habitat restoration efforts. Can J Fish Aquat Sci (Suppl.1): 136-141.

Karakuş U, Top N, Tepeköy EG, Britton JR, Tarkan AS. 2018. Life history characteristics of the potentially invasive Ponto-Caspian goby Neogobius fluviatilis in natural lakes from its native range (Black Sea region of Turkey). Mar Freshwater Res 69: $1544-1556$.

Knaepkens G, Knapen D, Hanfling B, Verheyen E, Eens M. 2002. Genetic diversity and condition factor: a significant relationship in Flemish but not in German populations of the European bullhead (Cottus gobio L.). Heredity 89: 280-287.

Kocovsky PM, Tallman JA, Jude DJ, Murphy DM, Brown JE, Stepien CA. 2011. Expansion of tubenose gobies Proterorhinus semilunaris into western Lake Erie and potential effect on native species. Biol Invasions 13: 2775-2784.

Kornis MS, Mercado-Silva N, Vander Zanden MJ. 2012. Twenty years of invasion: a review of round goby Neogobius melanostomus biology, spread and ecological implications. J Fish Biol 80: 235-285.

Kováč V, Copp GH, Sousa RP. 2009. Life-history traits of invasive bighead goby Neogobius kessleri from the middle Danube with a reflection of who may win the goby competition. J Appl Ichthyol 25: 33-37.

Ladich F, Kratochvil H. 1989. Sound production of the marmoreal goby Proterorhinus marmoratus (Pallas) (Gobiidae, Teleostei). Zoologische Jahrbücher. Abteilung für allgemeine Zoologie und Physiologie der Tiere 93: 501-504.

Le Cren ED. 1951. The length-weight relationship and seasonal cycle in gonad weight and condition in the perch (Perca fluviatilis). $J$ Anim Ecol 20: 201-219.

Lusk S, Halačka K, 1995. The first finding of the tubenose goby, Proterorhinus marmoratus in the Czech Republic. Folia Zool 44: 90-92.

Masó G, Latorre D, Tarkan AS, Vila-Gispert A, Almeida D. 2016. Inter-population plasticity in growth and reproduction of invasive bleak, Alburnus alburnus (Cyprinidae, Actinopterygii), in northeastern Iberian Peninsula. Folia Zool 65: 10-14.

Mikl L, Adámek Z, Všetičková L, Janáč M, Roche K, Šlapansky L, Jurajda P. 2017. Response of benthic macroinvertebrate assemblages to round (Neogobius melanostomus, Pallas 1814) and tubenose (Proterorhinus semilunaris, Heckel 1837) goby predation pressure. Hydrobiologia 785: 219.

Numann W. 1958. Research on Limnological and Fishery Sciences in Various Lakes of Anatolia and a Special Study on Common Carp Living in These Lakes. Monography from İstanbul University Science Faculty Hydrobiology Research Institute No: 7, İstanbul [in Turkish].

Ogle DH. 2017. FSA: Fisheries Stock Analysis. $R$ package version 0.8.16. 
Puntila R, Vilizzi, L, Lehtiniemi M, Copp GH. 2013. First application of FISK the freshwater Fish Invasiveness Screening Kit in Northern Europe: example of Southern Finland. Risk Anal 33: 1397-1403.

Ragimov DB. 1986. Reproduction of small goby species (Gobiidae) of the Caspian Sea. J Ichthyol 27: 58-65.

Ribeiro F, Elvira B, Collares-Pereira MJ, Moyle PB. 2008. Lifehistory traits of non-native fishes in Iberian watersheds across several invasion stages: a first approach. Biol Invasions 10: 89-102.

Roche KF, Janáč M, Jurajda P. 2013. A review of Gobiid expansion along the Danube-Rhine corridor - geopolitical change as a driver for invasion. Knowl Manag Aquat Ecosyst 411: 1-26.

Roy HE, Rabitsch W, Scalera R, Stewart A, Gallardo B, Genovesi P, Essl F, Adriaens T, Bacher S, Booy O, Branquart E. 2017. Developing a framework of minimum standards for the risk assessment of alien species. $J$ Appl Ecol 55: 526-538.

Semenov DY. 2011. Data on the morphometry and biology of tubenose goby Proterorhinus marmoratus (Pallas, 1814) in the Kuybyshev reservoir. Povolzski Ekologicheski Zhurnal 2: 237-242.

Simonović P, Tošić A, Vassilev M, Apostolou A, Mrdak D, Ristovska M, Kostov V, Nikolić V, Škraba D, Vilizzi L, Copp GH. 2013. Risk identification of non-native freshwater fishes in four countries of the Balkans Region using FISK. Mediterr Mar Sci 14: 369-376.

Smirnov AN. 1986. 'Fauna Ukrainy 8, Ryby (5): Okuneobraznye (byčkovidnyje), skorpenoobraznyje, kambaloobraznyje, udiljščikoobraznyje [Fauna Ukrainy 8, Fishes (5): Perciformes (Gobioidei), Scorpaeniformes, Pleuronectiformes, Lophiiformes]'. (Naukova Dumka, Kiev) [in Russian].

Tarkan AS, Gaygusuz Ö, Acıpınar H, Gürsoy Ç, Özulug M. 2006. Length-weight relationship of fishes from the Marmara region (NW-Turkey). J Appl Ichthyol 22: 271-273.

Tarkan AS, Gaygusuz Ö, Özulug M, Gürsoy Gaygusuz Ç, Saç G. 2009. Length-weight relationships of six freshwater fishes from the small streams flowing into Lake Sapanca, NW Turkey. $J$ Appl Ichthyol 25: 230-231.
Tarkan AS, Vilizzi L, Top N, Ekmekçi FG, Stebbing PD, Copp GH. 2017. Identification of potentially invasive freshwater fishes, including translocated species, in Turkey using the Aquatic Species Invasiveness Screening Kit (AS-ISK). Int Rev Hydrobiol 102: $47-56$.

Tarkan AS, Karakuş U, Tepeköy EG, Top N, Yalçın-Özdilek S, Partal N, Britton JR. 2018. Trophic interactions of two Ponto-Caspian gobies in the Turkish part of their native range. Turk J Fish Aquat Sci 18: 1279-1286.

Trippel EA, Harvey HH. 1987. Reproductive responses of five white sucker (Catostomus commersoni) populations in relation to lake acidity. Can J Fish Aquat Sci 44: 1018-1023.

Valová Z, Konecna M, Janác M, Jurajda P. 2015. Population and reproductive characteristics of a non-native western tubenose goby (Proterorhinus semilunaris) population unaffected by gobiid competitors. Aquat Invasions 10: 57-68.

Vanderploeg HA, Nalepa TF, Jude DJ, Mills, EL, Holeck KT, Liebig JR, Grigorovich IA, Ojaveer H. 2002. Dispersal and emerging ecological impacts of Ponto-Caspian species in the Laurentian Great Lakes. Can J Fish Aquat Sci 59: 1209-1228.

Vašek M, Všetičková L, Roche K, Jurajda P. 2014. Diet of two invading gobiid species (Proterorhinus semilunaris and Neogobius melanostomus) during the breeding and hatching season: no evidence of extensive predation on fish eggs and fry. Limnologica 46: 31-36.

Vilizzi L, Copp GH. 2013. Application of FISK, an invasiveness screening tool for non-native freshwater fishes, in the MurrayDarling Basin (south-eastern Australia). Risk Anal 33: 14321440.

Všetičková L, Janác M, Vašek M, Roche K, Jurajda P. 2014. Nonnative western tubenose gobies Proterorhinus semilunaris show distinct site, sex and age-related differences in diet. Knowl Manag Aquat Ecosyst 414: 10.

Wootton RJ. 1990. Ecology of Teleost Fishes. London: Kluwer Academic Publishers, p. 386.

Yankovskiy BA. 1966. Reproductive biology of some Azov gobies (Gobiidae). Gidrobiologicheskii Zhurnal 2: 48-52.

Cite this article as: Top N, Karakus U, Tepeköy EG, Britton JR, Tarkan AS. 2018. Plasticity in life history traits of the native Proterorhinus semilunaris suggests high adaptive capacity in its invasive range. Knowl. Manag. Aquat. Ecosyst., 419, 48. 